\title{
INVESTIGATION OF REVENUE SHARING, TRANSPARENCY AND FIRM PERFORMANCE TO PROFIT DISTRIBUTION MANAGEMENT
}

\author{
Mismiwati ${ }^{1)}$, Haryadi $^{2)}$, Tona Aurora Lubis ${ }^{3)}$, Enggar Diah Puspa Arum ${ }^{4)}$ \\ ${ }^{1)}$ Fakultas Ekonomi dan Bisnis Islam, UIN Raden Fatah Palembang, Palembang Indonesia \\ ${ }^{2,3,4)}$ Fakulras Ekonomi, Universitas Jambi, Jambi Indonesia \\ Corresponding email: mismiwati_uin@radenfatah.ac.id
}

\begin{abstract}
This study was conducted to determine the effect on Profit Distribution Management recorded in Bank Indonesia on financing for profit sharing, transparency and performance. Research conducted using RGEC Method to determine the level of performance in the company and the population of this study is a company listed in the Jakarta Islamic Index of 2012-2016. The results of this study indicate that mudharabah variables have an effect but not significant to PDM, ROA and CAR have significant effect to PDM while musharaka, transparency, FDR, GCG and BOPO have no significant effect to PDM.
\end{abstract}

Keywords: Profit Sharing, Transparency, Firm Performance, Profit Distribution Management

\section{Introduction}

Bank is a financial institution or company engaged in finance. Banks commonly known as Commercial Banks or Conventional Banks engaged in financial services, but at this time the banking world has been more developed with the emergence of banking institutions based on the religious sharia (especially Islam) in which is now known as the Bank of Sharia. Sharia Bank stood in Indonesia around 1992 which is based on Act Number 7 of 1992 as the legal basis of the bank and Government Regulation Number 72 of 1992 concerning Commercial Bank based on profit sharing principles as the legal basis of Sharia Bank and Government Regulation Number 73 concerning Rural Bank Sharia.

Financing is the provision of money or equivalent claims, based on a loan agreement or agreement between a financial institution and another party requiring the borrower to repay the debt after a certain period of time, in return or profit sharing (Rivai and Veithzal, 2008). The concept of profit-sharing may work if the depositors' funds in the bank are invested in the business, and the profit will be shared. Unlike customer deposits in a conventional bank, regardless of whether the deposits are channeled into the business or not, the bank is still obliged to pay interest, in addition to the profits obtained by the bank will not be distributed to its customers. Regardless of the amount of conventional bank profits, customers are paid only based on the percentage of the funds they keep (Rini, 2000).

Performance by Sedarmayanti (2007) in Anggraeni (2014) is the achievement/ achievement dealing with the task given. The work that can be achieved by a person or group of persons within an organization in accordance with their respective authorities and responsibilities, in an effort to achieve the objectives of the organization concerned legally, is not unlawful and in accordance with ethical morals. Mangkunegara (2005) in Pratiwi (2013) describes the performance as a result of work in quality and quantity achieved in order to carry out the task in accordance with the responsibilities given. Performance is measured using the RGEC method. According to Bank Indonesia Regulation No.13 / 1 / PBI / 2011, RGEC is an individual Bank rating of Banks using Risk-based Bank Rating.

In research Pratiwi (2013) which states that BOPO have a positive effect on profit distribution. This is supported by research from Maulina (2013) which says that BOPO has a positive effect on profit distribution. Meanwhile, according to Muniroh (2014) BOPO has a negative influence on Financial Performance. And while according to research Africano \& Mismiwati (2017) which says that BOPO negatively affect profit distribution management. In research Pratiwi (2013) which states that the CAR has a positive effect on profit distribution. This is also supported by research from Maulina (2013) which says that CAR has a positive effect on profit distribution. On the contrary, Hermanu's (2015) study shows that CAR negatively affects Profit Distribution Management at Sharia banks in Indonesia. And according to research Africano \& Mismiwati (2017) who said that CAR has no effect on profit distribution management.

Based on previous literature review and research that has been described, the hypotheses can be as follow below:

$\mathrm{H}_{1} \quad$ : Profit sharing has a positive effect on profit distribution management

$\mathrm{H}_{2} \quad$ : Transparency has a positive effect on profit distribution management

$\mathrm{H}_{3} \quad$ : $\quad$ FDR has a positive effect on profit distribution management

$\mathrm{H}_{4} \quad$ : GCG has a positive effect on profit distribution management

$\mathrm{H}_{5} \quad$ : ROA has a positive effect on profit distribution management 
$\mathrm{H}_{6} \quad$ : $\quad$ BOPO has a positive effect on profit distribution management

$\mathrm{H}_{7} \quad$ : CAR has a positive effect on profit distribution management

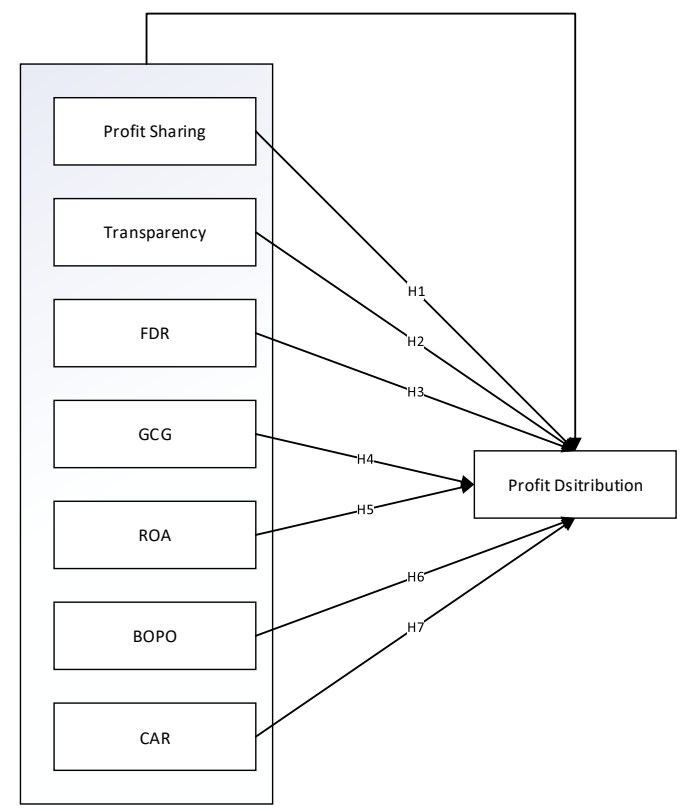

Source: developed for this study (2018)

Figure 1

Research Model

\section{Methods}

The object of this research is the effect of profit sharing, transparency and performance on profit distribution management. While the subject of the study studied is the Sharia Commercial Bank of 2012-2016 using annual reports. The required data is obtained from the annual report taken from the website of Bank Indonesia (www.bi.go.id), and additional data is retrieved through the company website as required.

\section{Result and Discussions}

The development of sharia industry has been informally initiated prior to the issuance of the formal legal framework as the foundation of sharia banking operations in Indonesia. Prior to 1992, several non-bank financing entities have been established which have implemented profit sharing concepts in their operational activities. It indicates the need of the community to the presence of financial institutions that can provide shariacompliant financial services.

In answering the needs of the community for the establishment of a sharia-compliant banking system, the government has included the possibility in the new Law, Law no. 7 of 1992 concerning banking has implicitly opened up opportunities for banking business activities that have operational base for the results of which are described in detail in government regulations with No. 72 of 1992 on banks based on the principle of profit sharing. The provisions of such legislation have been used as the legal basis for the operation of sharia banks in Indonesia which marked the beginning of the era of dual banking system (Dual Banking System) in Indonesia.

The development of sharia banking in Indonesia has become a benchmark of the success of sharia economic success. Bank Muamalat as the first sharia bank and became a pioneer for other sharia banks have previously implemented this system amid the proliferation of conventional banks. The monetary crisis that occurred in 1998 has drowned out conventional banks and many have been liquidated due to the failure of the interest system. While banks that implement the system of sharia can still exist and can survive.

Table 1 Test of Kolmogorov-Smirnov Normality

\begin{tabular}{lc}
\hline & Unstandardized Residual \\
\hline Kolmogorov-Smirnov Z & 0,712 \\
Asymp. Sig. (2-tailed) & 0,692 \\
\hline \multicolumn{2}{c}{ Source: SPSS Data Results (2018) }
\end{tabular}


Based on Table 1 obtained from Kolmogorov-Smirnov Z of 0.712 and Asymp. Sig. of 0.692 greater than 0.05 then it can be concluded normal distributed data.

A good regression model should not occur correlation between variables (no multicollinearity).

\begin{tabular}{ccc} 
Table 2 Multicollinearity & Test with Tolerance and VIF \\
\hline Model & Tolerance & VIF \\
\hline Mudharabah & 0,485 & 2,061 \\
\hline Musharaka & 0,372 & 2,686 \\
\hline Transparency & 0,827 & 1,209 \\
\hline FDR & 0,755 & 1,324 \\
\hline GCG & 0,733 & 1,365 \\
\hline ROA & 0,452 & 2,213 \\
\hline BOPO & 0,419 & 2,387 \\
\hline CAR & 0,425 & 2,356
\end{tabular}

Source: SPSS Data Results (2018)

Based on table 2 above, note that the tolerance value of all independent variables $>0.10$. VIF value of all independent variables $<10.00$. Based on the criteria in decision making can be concluded that this research does not happen multicollinearity.

Table 3 Heteroskedastistity test

\begin{tabular}{lc}
\hline \multicolumn{1}{c}{ Model } & Sig \\
\hline (Constant) & 0,435 \\
\hline Mudharabah & 0,218 \\
\hline Musharaka & 0,599 \\
\hline Transparency & 0,647 \\
\hline FDR & 0,627 \\
\hline GCG & 0,051 \\
\hline ROA & 0,402 \\
\hline BOPO & 0,529 \\
\hline Source: SPSS Data Results $(2018)$
\end{tabular}

Based on table 3 obtained sig from Mudharabah of 0.218 , sig of Musyarakah of 0.559 , sig of Transparency of 0.647 , sig of FDR of 0.627 , sig of GCG of 0.051 , sig of ROA of 0.402 and sig of BOPO of 0.529 greater than 0,05 it can be concluded that there is no Heteroskedastistity.

Table 4 Autocorrelation Test with Durbin-Watson

\begin{tabular}{lc}
\hline Model & Durbin-Watson \\
\hline 1 & 1,419 \\
\hline Source: SPSS Data Results (2018)
\end{tabular}

Based on Table 4 it is known that the DW value is 1,419. Based on the decision making criteria that the DW value is between -2 to +2 so it can be concluded there is no autocorrelation.

One way to determine linearity is by Lagrange Multiplier test by comparing the value of $\mathrm{c} 2$ count with c2 table. If the value of $\mathrm{c} 2$ counts > c2 table, then the hypothesis that the linear model is rejected.

Table 5 Linerity Test with Lagrance Multiplier

\begin{tabular}{cc}
\hline Model & R Square \\
\hline 1 & 0,040 \\
\hline \multicolumn{2}{l}{ Source: SPSS Data Results (2018) }
\end{tabular}

The coefficient of determination R2 essentially measures how far the model's ability to explain variations of independent variables. The value of the coefficient of determination is between 0 and 1 . The small value of R2 means the ability of independent variables to explain the variation of the dependent variable is very limited (Imam Ghozali, 2013).

Table 6 Coefficient of Determination Value

$\frac{\frac{\text { Model }}{1} \text { Adjusted R Square }}{\text { Source: SPSS Data Results (2018) }}$


The amount of adjusted R square 0.704 means that $70.4 \%$ of PDM is influenced by the eight independent variables Mudharabah, Musharaka, Transparency, FDR, GCG, ROA, BOPO and CAR while the rest (100 $70.4=29.6 \%$ ) - other causes beyond the model.

The statistical test $\mathrm{F}$ basically indicates whether all independent or independent variables included in the model have a mutual influence on the dependent or dependent variable. F test table results can be said to have an influence if Sig. $<0.05$ or F count $>$ F table. Here are the results of the F test table:

Table 7 F Test Results (Simultaneous)

\begin{tabular}{|c|c|}
\hline F & Sig. \\
\hline 10,826 & $0,000^{\mathrm{b}}$ \\
\hline
\end{tabular}

Source: SPSS Data Results (2018)

In conducting the test, it is known that the amount of data is $50(\mathrm{n}=50)$, the number of variables $9(\mathrm{k}=$ $9)$, and the significance level of $0.05(\alpha=0.05)$. The value of F table obtained from the test result is 2.17 and $\mathrm{F}$ arithmetic value $(10,826>2,17)$ and Sig value. $0,000<0.05$. With the results already obtained can be seen that $\mathrm{H}_{0}$ rejected and $\mathrm{Ha}$ accepted, which means that all independent variables is a significant explanation of the dependent variable. In other words, accept an alternative hypothesis which states that all independent variables simultaneously and significantly affect the dependent variable. Then the regression model can be used to predict PDM or Mudharabah, Musharaka, Transparency, FDR, GCG, ROA, BOPO and CAR simultanly affect PDM.

Table 8 Test Statistics $\mathbf{t}$

\begin{tabular}{lcc}
\hline \multicolumn{1}{c}{ Model } & T & Sig \\
\hline (Constant) & 0,859 & 0,398 \\
\hline Mudharabah & $-2,029$ & 0,053 \\
\hline Musharaka & 0,828 & 0,415 \\
\hline Transparency & 0,830 & 0,414 \\
\hline FDR & $-0,022$ & 0,982 \\
\hline GCG & 0,682 & 0,502 \\
\hline ROA & 7,043 & 0,000 \\
\hline BOPO & $-1,049$ & 0,304 \\
\hline CAR & $-2,391$ & 0,025 \\
\hline Source: SPSS Data Results $(2018)$ &
\end{tabular}

In conducting the test, it is known that the amount of data is $50(n=50)$, the number of independent variables is $9(\mathrm{k}=9)$, and the significance level is $0.05(\alpha=0.05)$ with the value of table equal to 1,683 .

The result of the research shows that Mudharabah financing is influential but not significant to profit distribution management. Theoretical study of the results of research on Islamic banking in Indonesia using the concept of mudaraba that runs side by side with the concept of borrowing the interest system as a way to finance various economic activities. However, after Islamic Banking comes, all financial transactions based on usury (interest) are prohibited and all funds must be channeled on the basis of profit sharing (profit and loss sharing). The amount of financing will determine the rate at which Islamic banks do profit distribution. The higher the ratio of financing proportion the higher the PDM level. This is in accordance with Farook's research, dkk (2012), Kartika and Adityawarman (2012), Mulyo and Mutmainah (2013), and Judge (2014) concluding that Sharing / Mudharabah Financing has a positive effect on PDM.

The results showed that Musharaka financing has no effect on profit distribution management. Musharaka financing is a financing done by the bank where the bank acts as the owner of the fund or participate as a business partner managed by other parties. Profit gained in accordance with how much capital invested that has been agreed at the beginning of the agreement. If the business fails, the loss will be borne together in proportion to equity (Rivai, 2010: 193). In Musharaka financing, sharia banks do not provide full capital, but the given capital is part of the total required capital. Sharia banks can include capital in accordance with the portion agreed with the customer. Because of its many problematic financing of musharaka products, this is why it does not affect its musharaka to PDM.

The results of statistical tests on Transparency variables show that these variables have no effect on Profit Distribution Management, this is not in accordance with the hypothesis. This shows that the bank in the profit sharing (Profit Distribution) is not influenced by Transparency one of the factors that the cause is there is still a problem that becomes an obstacle to the development of sharia-based investment that is not yet uniformly understanding or knowledge of Indonesian society about sharia investment (Yuliana, 2010: 31)

The results showed that FDR has no effect on profit distribution management. Assessment of the performance of sharia banks as intermediary institutions, can use the Financing to Deposit Ratio (FDR), which is the ratio between financing disbursed by banks with third party funds collected by banks and bank capital 
concerned. This ratio is used to measure the extent to which loan funds are sourced from third party funds. The high of this ratio indicates the level of liquidity of the bank. So the higher the Financing to Deposit Ratio (FDR) of a bank, it means described as a bank that is less liquid than the bank having a smaller ratio figure. (Muhammad, 2005: 55). Distribution of financing by using the third fund is done to avoid any funds that do not work. Given the idle funds or unfunded funds, it will reduce the chances for banks to make a profit. This is in agreement with the Judge's (2014) study which says that FDR has no effect on PDM.

The results showed that GCG had no effect on PDM. The average value of GCG of sharia banking is very good, that is 1.6729. However, Sharia Banking has an average value of PDM-391.6. The small value of PDM is caused by the lack of fund disbursement to the public. The distribution of financing has decreased due to the application of prudent principles applied by the management in the distribution of financing. With the decrease in financing disbursed, then the profit also decreased by the bank. When the resulting profit decreases, then the PDM also decreases. Based on this, it can be concluded that a good implementation of GCG at the bank does not guarantee to increase the PDM in question.

The results showed that ROA has a positive effect on profit distribution management. ROA is one of the ratios used to measure the company's effectiveness in generating profits by utilizing its total assets. ROA is the ratio between profit before tax to the average total bank asset. The greater the value of ROA, the greater the performance of the company. Return On Assets (ROA) focuses the company's ability to earn earnings in the company's operations by utilizing its assets. ROA is important for sharia banking because ROA is used to measure the company's effectiveness in generating profit by utilizing its assets. The lower (smaller) ratio is getting less good and vice versa, meaning that this ratio is used to measure the effectiveness of the overall operation of the company. This is similar to Pratiwi's research (2013) which states that ROA has a positive effect on profit distribution. The same thing is obtained by Mira Daelawati, Rustam Hidayat and Dwiatmanto (2010) which shows that ROA has an effect on profit distribution.

Operating income or BOPO operational costs can be defined as the ratio to compare operational costs with operating income in measuring the efficiency and ability of banks in supporting operational activities (Rivai \& Arifin: 866). The higher the ratio will be the worse the performance of the bank, because the cost is greater than the revenue generated. On the contrary, if this ratio is low, it can be said that the better the performance of the bank because the cost incurred is lower than the income received. Based on the analysis that has been done, obtained an average BOPO of 94.315 or equal to 0.94315 . These results explain that the average cost derived from the operational performance of Islamic banks is very high compared with the revenue generated. If the costs incurred high for the results obtained will be relatively small, so the manager will automatically not be motivated to do high PDM, because it will be difficult to cover the possibility of risks that will arise. So it can be concluded that BOPO has no effect on PDM. This research is consistent with Kusuma (2013) and Imawan (2014) research which states that BOPO has no significant effect on PDM. However, the results of this study are not consistent with research conducted by Rizaludin (2013) which states that BOPO has a significant effect on PDM.

The results show that CAR has an effect on profit distribution management. Capital adequacy describes the ability of banks to maintain capital to cover the risk of losses that may arise from the placement of funds in risky productive assets, as well as for financing in fixed assets and investments. Capital adequacy ratio (CAR) can be used to measure capital adequacy in sharia banks (Muhammad, 2005). The greater this ratio, the health of the bank is said to improve. This is because the capital owned by banks is able to cover the risk of losses arising from the placement of funds in productive assets that contain risks, and can be used to finance the planting in fixed assets and investment. CAR (Capital Adequacy Ratio) is used to determine the performance of financial statements. In general, CAR (Capital Adequacy Ratio) is one important factor in the development of business and accommodate the risk of loss, the higher the CAR, the stronger the bank's ability to bear the risk of any risky credit / earning assets. If the high CAR value (according to the BI 8\%) means that the bank is able to finance the bank's operations, the circumstances favoring the bank will contribute substantially to profitability (Mudrajad Kuncoro and Suhardjono, 2002: 573). CAR (Capital Adequacy Ratio) is the ratio of bank performance to measure capital adequacy owned by banks to support the assets that contain and generate risks, such as loans provided to customers. So this is in accordance with research Pratiwi (2013), Maulina (2013), Eko Wahyu (2016) which says that CAR has a positive effect on profit distribution.

\section{Conclusions}

The following conclusions from the results of research and discussion include:

Mudharabah proved to have an effect but not significant to Profit Distribution Management based on t count equal, While Musyarakah no significant effect on Profit Distribution Management. Transparency is not proven to significantly influence Profit Distribution Management. FDR is not proven to significantly influence Profit Distribution Management. GCG is not proven to significantly influence Profit Distribution Management. ROA proved to have significant effect on Profit Distribution Management. BOPO is not proven to significantly influence Profit Distribution Management. CAR proved to significantly influence Profit Distribution Management. 


\section{References}

Abbas Mirakhor, Zamir Iqbal, (2008). Pengantar Keuangan Islam Teori dan Praktik, Jakarta: Kencana

Abdullah, Man An, (2010), “Good corporate governance perbankan syariah di indonesia”, Jogjakarta, Ar-ruz Media.

Adrian Sutedi, (2009). Perbankan Syariah Tinjauan Dari Beberapa Segi Hukum, (Bogor, Ghalia Indonesia, hal .36

Africano, Fernando, Akbar, Dinnul Alfian dan Lidyah, Rika. (2017). Pengujian Sinyal Perusahaan untuk mendapatkan Kepercayaan Pemangku Kepentingan. Simposium Nasional Akuntansi XX Jember.

Africano, Fernando, Megawati, Elizabeth Sri \& Parlindungan, Ricardo, (2017). Factors Affecting Profit Distribution Management of Syariah Banks in Indonesia". American Scientific Publishers.

Africano, Fernando, Mismiwati, (2017). Pengaruh Faktor Internal Bank Terhadap Pembiayaan Bagi Hasil Serta Implikasinya pada Profit Distribution Management Bank Syariah. http://pnj.ac.id/news/index/1683/Edisi-Juni-2017.html

Amirullah, (2002).Perilaku Konsumen, Yogyakarta, Graha Ilmu, Cet.1

Amrillah, (2010). "Efisiensi Perbankan Syariah di Indonesia Tahun 2005-2009". Program Pascasarjana. Universitas Diponogoro Semarang. Semarang. Indonesia.

Andi, Prasetyo. (2011). Analisis Kinerja Pemerintah Daerah Kabupaten karanganyar dilihat dari Rasio Pendapatan Daerah pada APBD 2006-2008. Skripsi. Surakarta. Universitas Muhammadiyah Surakarta.

Andriyanti, Ani \& Wasilah. (2010). Faktor-Faktor Yang Mempengaruhi Jumlah Penghimpunan Dana Pihak Ketiga. Simposium Nasional Akuntansi XIII

Anshori, Abdul Gofur, (2009). Perbankan Syariah Indonesia. Yogyakarta : Gadjah Mada University Press.

Bank Indonesia, Sistem Penilaian Tingkat Kesehatan Bank Umum, Bank Indonesia 2004 (SE BI No.6/23/DNDP)

Bambang Supomo dan Nur Indriantoro, (2002), Metodologi Penelitian Bisnis, Cetakan Kedua, Yogyakara; Penerbit BFEE UGM.

Bisnis Bank Syariah, (2017). Berpeluang Terus Melonjak, Ini Alasannya. http://www.republika.co.id/berita/ekonomi/syariahekonomi/17/01/18/ojy976382-bisnis-bank-syariah2017-berpeluang-terus-melonjak-ini-alasannya. Diakses pada tanggal 10 September 2017.

Dendawijaya, Lukman, (2008). Manajemen Perbankan. Penerbit. Ghalia Indonesia. Jakarta.

Ekalagati, Agrian Metasari, (2014). Pengaruh Kinerja Keuangan terhadap Tingkat Bagi Hasil Deposito Mudharabah.

Errico, Luca \& Farahbaksh, M, (1998). Islamic Banking Issues in Prudential Regulations and Supervision.

Farook, S., Hassan, M. K dan Clinch, G. (2012). Profit Distribution Management by Islamic Banks: An Empirical Investigation. The Quarterly review of Economics and Finance, vol.52 (3): 333-347. ELSEVIER.

Farvaque, E., Refait-Alexandre, C., \& Saidane, D. (2011). "Corporate Disclosure a Review of its (Direct and Indirect) Benefits and Coasts". Economie Internationale, (4), 5-31.

Ghozali, Imam. (2007). Aplikasi Analisis Multivariate Dengan Program Spss. Semarang: Bp Universitas Diponegoro.

Ghozali, Imam. (2013). Aplikasi Analisis Multivariate dengan Program IBM SPSS 21 Edisi 21. Semarang: Badan Penerbit Diponogoro.

Gilang, Nur Giannini. (2013). Faktor yang Mempengaruhi Pembiayaan Mudharabah pada Bank Umum Syariah di Indonesia. Accounting Analysis Journal. AAJ 2 (1).

Hafiz, Abdul Tanjung, (2010). Akuntansi, Transparansi dan Akuntabilitas Keuangan Publik (Sebuah Tantangan).

Hakim, A.F, (2014).Pengaruh Capital Adequancy Ratio, Loan Asset To Total Asset, Penyisihan Penghapusan Aset Produktif, Financing to Deposit Ratio dan Tingkat Suku Bunga Terhadap Profit Distribution Management Pada Bank Syariah. Diss, UPN Veteran, Yogyakarta.

Husnelly, (2003). Faktor-faktor yang Mempengaruhi Investasi Dana Masyarakat pada Bank Syariah (Studi Kasus pada Bank Syariah Mandiri). Tesis. Universitas Indonesia.

Hidayat ,Eko Wahyu, (2016). Faktor - Faktor yanf Mempengaruhi Profit Distribution Management Bank Umum Syariah di Indonesia Periode 2011-2015. UIN Sunan Kalijaga:Yogyakarta.

Ismail, (2010). Manajemen Perbankan : Dari Teori Menuju Aplikasi. Jakarta: Kencana.

Kartika, (2014). Analisis Faktor-Faktor yang Mempengaruhi Profit Distribution Management Universitas Diponogoro : Semarang.

Khairunnisa, Delta. (2002). Preferensi Masyarakat Terhadap Bank Syariah (Studi Kasus Bank Muamalat Indonesia dan BNI Syariah). Makalah pada Simposium Nasional. Yogyakarta: Sistem Ekonomi Islam, P3EI-FEUII.

Kristianten, (2006). Transparansi Anggaran Pemerintah. Jakarta :Rineka Cipta.

Kuncoro dan Suhardjono,(2002), Manajemen Perbankan (Teori dan Aplikasi), Edisi Pertama, Penerbit BPFE , Yogyakarta 
Lahrech, N., Lahrech, A., Boulaksil, Y. 2014. Transparency and performance in Islamic banking Implications on profit distribution. International Journal of Islamic and Middle Eastern Finance and Management, vol 7(1):61-88. Emerald Group Publishing Limited.

Muhammad. 2005. Manajemen Pembiayaan Syariah. Yogyakarta: UPP AMP YKPN

Muhammad, 2009. Model-model Akad Pembiayaan di Bank Syariah (Panduan Teknis Pembuatan Akad), Yogyakarta: UII Press.

Nurhayati, Sri., Wasilah. (2014). Akuntansi Syariah di Indonesia. Jakarta: Salemba Empat.

Panggah, Mulyo Gagat. (2012). Faktor-Faktor Yang Mempengaruhi Profit Distribution Management Atas Simpanan Deposan Pada Bank Syariah Di Indonesia Periode 2008-2011. Banjarmasin: SNA 15.

Poerwadarminta, W.J.S. (200). Kamus Umum Bahasa Indonesia. Balai Pustaka. Jakarta.

Prasetyo, B. \& Jannah, L.M., (2011). Metode Penelitian Kuantitatif Cetakan 6, Jakarta: PT Raja Grafindo Persada.

Rahman, Dahlan A, (2004). Analisa Faktor Internal Terhadap Distribusi Bagi Hasil Bank Syariah (Studi Kasus Pada PT. Bank Syariah Mandiri). Tesis Program Pascasarjana. Universitas Diponogoro Semarang.

Reggi Merdeka Wati, (2016). Faktor - Faktor Mempengaruhi Profit Distribution Management pada Perbankan Syariah di Indonesia Periode 2012-2014.

Rensi Permatasari, (2015). Pengaruh Transparansi dan Kinerja terhadap Profit Distribution. Universitas Diponogoro.

Rivai, Veithzal dan Veithzal, A.P, (2008). Islamic Financial Management. Rajawali Pers, Jakart., Indonesia.

Rodoni, Ahmad dan Hamid, Abdul, (2008). Lembaga Keuangan Syariah, Jakarta, Zikrul Hakim,.

Suriadin, Irma, (2015). Analisis Faktor-Faktor yang Mempengaruhi Profit Distribution Management pada Perbankan Syariah.

Tamba, Erida. (2011). Pengaruh Struktur Kepemilikan terhadap Pengungkapan Tanggung Jawab Sosial Perusahaan. Skripsi. Universitas Diponegoro.

Tugiantoro, Suyanto, (2014). The Factors Affecting Profit Distribution: An Emperical Study on Islamic Banking”. China-USA Business Review, ISSN 1537-1514, Vol 13 No. 5, 338-346.

Ulfah, (2017. "Determinan Profit Distribution Management Bank Syariah di Indonesia". Universitas Negeri Yogyakarta.

Wahyuni, Mirasanti, (2016). Pengaruh Volume Pembiayaan Bagi Hasil dan Pembiayaan Murabahah terhadap Kinerja Keuangan Bank Umum Syariah dengan NPF sebagai Variabel Moderasi. STIE Bank BPD : Jawa Tengah.

Wibowo, Edhi Satriyo dan Syaichu, Muhammad. (2013). Analisis Pengaruh Suku Bunga, Inflasi, CAR, BOPO, NPF terhadap Profitabilitas. Dipenogoro Journal Of Accounting, Vol 2 No 2.

Wiwin, Masruroh, Fitriani \& Effendi Rochman, (2016). Analisis Profit Distribution Management (PDM) Bank Syariah di Indonesia Periode 2010-2014. Universitas Jember.

\section{Authors' Bibliography}

Mismiwati, was born in Palembang, Sumatera Selatan, October $27^{\text {th }}, 1968$. She graduated the bachelor degree from Economic Faculty of Muhammadiyah University in 1986, and master degree from Master of Agriculture of Brawijaya University in 1996.

Currently, Mismiwati on progress to accomplish the doctoral program of Finance Management from Economic Faculty of Jambi University in Jambi. 